\title{
TU/e EmonOWEN

\section{Modelling of chloride binding related to hydration products in slag-blended cements}

\section{Citation for published version (APA):}

Florea, M. V. A., \& Brouwers, H. J. H. (2014). Modelling of chloride binding related to hydration products in slagblended cements. Construction and Building Materials, 64, 421-430.

https://doi.org/10.1016/j.conbuildmat.2014.04.038

DOI:

10.1016/j.conbuildmat.2014.04.038

Document status and date:

Published: 01/01/2014

\section{Document Version:}

Publisher's PDF, also known as Version of Record (includes final page, issue and volume numbers)

\section{Please check the document version of this publication:}

- A submitted manuscript is the version of the article upon submission and before peer-review. There can be important differences between the submitted version and the official published version of record. People interested in the research are advised to contact the author for the final version of the publication, or visit the $\mathrm{DOI}$ to the publisher's website.

- The final author version and the galley proof are versions of the publication after peer review.

- The final published version features the final layout of the paper including the volume, issue and page numbers.

Link to publication

\section{General rights}

Copyright and moral rights for the publications made accessible in the public portal are retained by the authors and/or other copyright owners and it is a condition of accessing publications that users recognise and abide by the legal requirements associated with these rights.

- Users may download and print one copy of any publication from the public portal for the purpose of private study or research.

- You may not further distribute the material or use it for any profit-making activity or commercial gain

- You may freely distribute the URL identifying the publication in the public portal.

If the publication is distributed under the terms of Article 25fa of the Dutch Copyright Act, indicated by the "Taverne" license above, please follow below link for the End User Agreement:

www.tue.nl/taverne

Take down policy

If you believe that this document breaches copyright please contact us at:

openaccess@tue.nl

providing details and we will investigate your claim. 


\title{
Modelling of chloride binding related to hydration products in slag-blended cements
}

\author{
M.V.A. Florea *, H.J.H. Brouwers \\ Department of the Built Environment, Eindhoven University of Technology, P.O. Box 513, 5600 MB Eindhoven, The Netherlands
}

\section{H I G H L I G H T S}

- The composition of the slag is crucial to the chloride binding capacity of a paste.

- The interaction between the slag and OPC components is taken into account.

- The $\mathrm{C}-\mathrm{S}-\mathrm{A}-\mathrm{H}$ phase binds approximately two thirds of the total bound chlorides.

- The remaining third is attributed to AFm phases.

- The results of the model are highly improved from a previous model from literature.

\section{A R T I C L E I N F O}

\section{Article history:}

Received 31 July 2013

Received in revised form 19 March 2014

Accepted 2 April 2014

Available online 4 May 2014

\section{Keywords:}

Slag-blended cement

Hydration products

Cement paste

Chloride ions

Bound chlorides

Isotherms

Modelling

\begin{abstract}
A B S T R A C T
An improved hydration model of slag-blended cements, taking into account new insights, is used to estimate and quantify the hydration products of slag-blended cements. Individual chloride binding isotherms are used to correlate these amounts of hydration products with the amount of bound chlorides. A number of parameters are directly or indirectly taken into account when estimating the chloride binding ability of a slag-blended cement paste: cement composition, slag content, water/binder ratio, curing age, and free chloride concentration. The model allows the study of the breakdown of bound chlorides by hydration products and their source - either the OPC or the slag.
\end{abstract}

(c) 2014 Elsevier Ltd. All rights reserved.

\section{Introduction}

The durability of concrete structures in marine environments is strongly related to their deterioration under chloride attack. The chloride ions, responsible for the initiation of the corrosion mechanism, intrude from the external medium into the concrete. A part of the intruding chloride ions will be retained by the hydration products of the binder in concrete, either through chemical binding or by physical adsorption [1]. These retained chloride ions are generically referred to as "bound chlorides". Chloride ions that are not bound by hydration products (termed "free chlorides") are able to travel through the pore solution of the binder matrix to the level of the rebars. When a certain threshold concentration of chlorides is reached at the concrete-reinforcement interface,

\footnotetext{
* Corresponding author. Tel.: +31 4024746 87; fax: +31 402438595

E-mail address: m.v.a.florea@tue.nl (M.V.A. Florea).
}

the corrosion of the steel rebars is initiated. Therefore, chloride binding can delay the achieving of the threshold chloride concentration at the level of the reinforcement by removing chloride ions from the pore solution [2,3]. Quantifying this process helps to more accurately predict the service-life of reinforced concrete structures exposed to chloride attack, and allows for a better planning of their maintenance and repair periods. Another important purpose of studying chloride binding is the design of new cement mixes that are able to slow down chloride intrusion, thus improving the durability of future marine structures.

The source of chlorides in this study is considered to be $\mathrm{NaCl}$, as explained in [1]. The typical concentration of $\mathrm{NaCl}$ in seawater is fairly constant, ranging between 0.6 and $0.7 \mathrm{~mol} \mathrm{Cl}^{-} / \mathrm{l}$ (M) seawater. In the case of salty lakes, the chloride concentration can reach over $3 \mathrm{M}$. A widely-used accelerated test for determining chloride ingress into concrete, the Rapid Chloride Migration (RCM) test, uses a value for the concentration of the external solution of 
$\sim 1.8 \mathrm{~mol} \mathrm{NaCl} / \mathrm{l}(1.83 \mathrm{M})$ immersion solution [4]. Therefore, the range of $\mathrm{NaCl}$ concentration used in this study is $0-3 \mathrm{M}$, the same as employed in [1].

A number of studies have considered the ability of slag-blended cements to resist chloride attack [2,5-8]. A consensus exists upon the increased capacity of slag blended cements to bind chlorides, compared to pure OPC. This phenomenon has been attributed to the higher alumina content of slag [7], or to the $\left[\mathrm{OH}^{-}\right] /\left[\mathrm{Cl}^{-}\right]$ratio [5] and the negative role of sulphates has been highlighted [9]. In this study, only data obtained by the intrusion of external chloride ions into the sample [6] were employed, as opposed to internallymixed chlorides $[5,8]$. Also of importance was the determination of complete chloride binding isotherms [6] as opposed to the chloride binding in one specific external chloride concentration point $[5,8]$ and the availability of the compositional data regarding the OPC and slag employed [7]. All data employed in this study regarding chloride binding (selected from [6]) has been obtained using the "equilibrium method", in which the crushed hardened sample is kept in a $\mathrm{NaCl}$ solution of known concentration until equilibrium is reached.

In order to relate the amount of bound chlorides to the individual chloride binding capacity of each hydrated phase, a hydration model for slag-blended cements was needed. For this purpose, a combination of the OPC hydration model employed [1], based on the work of Brouwers [10-12], the slag-blended cement hydration model by $[13,14]$ and newer findings from literature [15-18] are used.

The binding ability of slag-blended cements comes from the interaction between the hydration of the cement and that of the slag. The two components react with different rates, and the slag hydration is activated by the portlandite formed during the OPC hydration. The two separate hydration processes lead to the formation of hydration products, some of which can be traced back to the reaction of OPC components, some to the reaction of slag with water and portlandite, and some which are common to both processes. Here, the hydration of the OPC-component and the slag one will also be considered separately for the modelling point of view, even though the consumption of portlandite is not their only interaction in real OPC-slag systems (as detailed in Section 2).

\section{The paste model}

\subsection{The hydration of the OPC component}

As described in [1], the hydration of OPC is modelled based on a study of Brouwers [10-12] and takes into consideration the particular case of no carbonation. Table 1 reviews the chemical equations that describe the hydration of OPC under water-saturated conditions, while Table 2 details the molar equations used to compute the amounts of formed hydration products. The same notations used in [1] were kept, with the exception of the superscript OPC,

Table 1

The chemical equations describing the formation of saturated (100\% r.h.) hydration products from slag-blended cements [10-12].

\begin{tabular}{|c|c|}
\hline $\mathrm{C}_{3} \mathrm{~S}+4.5 \mathrm{H} \rightarrow \mathrm{C}_{1.7} \mathrm{SH}_{3.2}+1.3 \mathrm{CH}$ & $(1.1)$ \\
\hline $\mathrm{C}_{2} \mathrm{~S}+3.5 \mathrm{H} \rightarrow \mathrm{C}_{1.7} \mathrm{SH}_{3.2}+0.3 \mathrm{CH}$ & $(1.2)$ \\
\hline $\mathrm{C}_{3} \mathrm{~A}+\mathrm{C} \overline{\mathrm{S}}+14 \mathrm{H} \rightarrow \mathrm{C}_{4} \mathrm{~A} \overline{\mathrm{S}} \mathrm{H}_{14}$ & $(1.3)$ \\
\hline $\begin{array}{l}\mathrm{C}_{3} \mathrm{~A}+\mathrm{CH}+21 \mathrm{H} \rightarrow \mathrm{C}_{4} \mathrm{AH}_{22} \\
\mathrm{C}_{2} \mathrm{~A}+3 \mathrm{C} \overline{\mathrm{S}}+36 \mathrm{H} \rightarrow \mathrm{C}_{6} \mathrm{~A}_{2} \mathrm{H}_{26}\end{array}$ & $\begin{array}{l}(1.4) \\
(1.5)\end{array}$ \\
\hline $\begin{array}{l}\mathrm{C}_{3} \mathrm{~A}+3 \mathrm{CS}+36 \mathrm{H} \rightarrow \mathrm{C}_{6} \mathrm{AS}_{3} \mathrm{H}_{36} \\
\mathrm{C}_{4} \mathrm{AF}+2 \mathrm{C}_{3} \mathrm{~S}+22 \mathrm{H} \rightarrow \mathrm{C}_{6} \mathrm{AFS}_{2} \mathrm{H}_{18}+4 \mathrm{CH}\end{array}$ & (1.6) \\
\hline $\mathrm{C}_{4} \mathrm{AF}+2 \mathrm{C}_{2} \mathrm{~S}+2 \mathrm{OH} \rightarrow \mathrm{C}_{6} \mathrm{AFS}_{2} \mathrm{H}_{18}+2 \mathrm{CH}$ & $(1.7)$ \\
\hline $\begin{array}{c}\mathrm{C}_{\mathrm{n}_{\mathrm{c}}^{\mathrm{s}}} \mathrm{S}_{\mathrm{n}_{\mathrm{s}}^{\mathrm{s}}} \mathrm{A}_{\mathrm{n}_{\mathrm{A}}^{\mathrm{sl}}} \mathrm{M}_{\mathrm{n}_{\mathrm{M}}^{\mathrm{sl}}} \overline{\mathrm{S}}_{\mathrm{n}_{\mathrm{s}}^{\mathrm{sl}}} \mathrm{F}_{\mathrm{n}_{\mathrm{F}}^{\mathrm{sl}}}+n_{\mathrm{H}} \mathrm{H}+n_{\mathrm{CH}} \rightarrow n_{\mathrm{C}-\mathrm{S}-\mathrm{H}}^{\mathrm{sl}} \mathrm{C}_{\mathrm{a}} \mathrm{SA}_{\mathrm{b}} \mathrm{H}_{(\mathrm{a}+1.5)}+n_{\mathrm{HT}}^{\mathrm{sl}} \mathrm{M}_{5} \mathrm{AH}_{13}+ \\
n_{\mathrm{HG}}^{\mathrm{sl}} \mathrm{C}_{6} \mathrm{AFS}_{2} \mathrm{H}_{8}+n_{\mathrm{AFt}}^{\mathrm{sl}} \mathrm{C}_{6} A \overline{\mathrm{S}}_{3} \mathrm{H}_{32}+n_{\mathrm{HO}-\mathrm{AFm}_{4}}^{\mathrm{sl}} \mathrm{C}_{4} \mathrm{AH}_{13}\end{array}$ & $(1.8)$ \\
\hline
\end{tabular}

Table 2

Molar relations between the amounts of hydration products and the mineral composition of OPC [10-12], as described in Section 2.1.

\begin{tabular}{|c|c|}
\hline$n_{\mathrm{C}_{4} \mathrm{~A} \overline{\mathrm{S}} \mathrm{H}_{14}}^{\mathrm{OPC}}=\alpha \cdot 0.5 n_{\mathrm{C} \overline{\mathrm{S}}}$ & (2.1) \\
\hline$n_{\mathrm{C}_{4} \mathrm{AH} \mathrm{H}_{22}}^{\mathrm{OPC}}=\alpha\left(n_{\mathrm{C}_{3} \mathrm{~A}}-0.5 n_{\mathrm{CS}}\right)$ & (2.2) \\
\hline$n_{\mathrm{C}_{6} \mathrm{AS}_{3} \mathrm{H}_{36}}^{\mathrm{OPC}}=\alpha \cdot 0.25 n_{\mathrm{C} \overline{\mathrm{S}}}$ & (2.3) \\
\hline$n_{\mathrm{C}_{1.7} \mathrm{SH}_{3.2}}^{\mathrm{OPC}}=\alpha\left(n_{\mathrm{C}_{3} \mathrm{~S}}+n_{\mathrm{C}_{2} \mathrm{~S}}-2 n_{\mathrm{C}_{4} \mathrm{AF}}\right)$ & $(2.4)$ \\
\hline$n_{\mathrm{C}_{6} \mathrm{AFS}_{2} \mathrm{H}_{18}}^{\mathrm{OPC}}=\alpha \cdot n_{\mathrm{C}_{4} \mathrm{AF}}$ & (2.5) \\
\hline$n_{\mathrm{CH}}^{\mathrm{OPC}}=\alpha\left(1.3 n_{\mathrm{C}_{3} \mathrm{~S}}+0.3 n_{\mathrm{C}_{2} \mathrm{~S}}-n_{\mathrm{C}_{3} \mathrm{~A}}+1.4 n_{\mathrm{C}_{4} \mathrm{AF}}+0.5 n_{\mathrm{CS}}\right)$ & (2.6) \\
\hline
\end{tabular}

used to differentiate these hydration products from the ones of the slag component.

As this OPC hydration model is extensively described in $[3,10$ 12 ], no further details will be given here. One observation should be made, however, on the composition of $\mathrm{C}-\mathrm{S}-\mathrm{H}$, which will be relevant further. A number of studies $[15,19,20]$ have reported a $\mathrm{C} / \mathrm{S}$ ratio of $1.8-1.85$ for pure $\mathrm{C}-\mathrm{S}-\mathrm{H}$ in OPC pastes, together with a substitution of the Si by Al. The A/S ratio in OPC C-S-H was found to be roughly $0.08[15,19]$. These values would lead to a $C /(S+A)$ value of 1.7 , which is consistent with [1]. However, the initial OPC hydration model does not take into account the Al substitution into $\mathrm{C}-\mathrm{S}-\mathrm{H}$, but considers $\mathrm{C} / \mathrm{S}$ to be 1.7 . Hence, the $\mathrm{C}-\mathrm{S}-\mathrm{H}$ structure $\mathrm{C}_{1.7} \mathrm{SH}_{3.2}$, used so far to describe composition of this hydration product, will be also considered in this article for the hydration of OPC. This choice will be described also from the chloride binding point of view in Section 4.2. In the case of slag-blended paste, the notation " $\mathrm{C}-\mathrm{S}-\mathrm{A}-\mathrm{H}$ " will be used to describe the calcium aluminosilicate hydrate phase, which is known to be able to incorporate higher alumina amounts [15,18-20].

An important point is the way the mass of sample will be calculated throughout this study. There are three types of samples which will be considered: pure OPC hydrated pastes, termed HCP1-HCP3 for "hardened cement paste", OPC-slag blended hydrated pastes, termed S1-S5 and theoretically computed "slag only" in which only the hydration products formed with the aid of $\mathrm{CH}$ (which is generated by hydrated OPC) are considered to constitute the sample (further details in Section 5). Moreover, the masses of all these samples will be computed at $11 \%$ r.h. The experimental data concerning the chloride binding capacity of hardened pastes employed in this study [6] are also based on samples dried at $11 \% \mathrm{r} . \mathrm{h}$. The water loss of certain hydration products upon drying has been estimated in [10-12,21]. This phenomenon leads to a decrease of molecular mass of the hydration products; however, the molar quantities are unaffected.

Using the molar amounts computed using the equations in Tables 2-4, and the molecular masses of all considered hydration products at $100 \%$ r.h. and $11 \%$ r.h. (Table 5), the mass of each hydrated product at either of the two relative humidities considered can be computed:

$$
\begin{aligned}
& m_{\mathrm{C}_{1.7}}^{\mathrm{OPC}} \mathrm{SH}_{2.1}=n_{\mathrm{C}_{1.7}}^{\mathrm{OPC}} \mathrm{SH}_{3.2} \mathrm{M}_{\mathrm{C}_{1.7} \mathrm{SH}_{2.1}} \text {; } \\
& m_{\mathrm{C}_{\mathrm{a}} \mathrm{SA}_{\mathrm{b}} \mathrm{H}_{(\mathrm{a}+0.5)}}^{\mathrm{sl}}=n_{\mathrm{C}_{\mathrm{a}} \mathrm{SA}_{\mathrm{b}} \mathrm{H}_{(\mathrm{a}+1.5)}}^{\mathrm{sl}} \mathrm{M}_{\mathrm{C}_{\mathrm{a}} \mathrm{SA}_{\mathrm{b}} \mathrm{H}_{(\mathrm{a}+0.5)}} \text {; } \\
& m_{\bar{C}_{\bar{a}} S A_{b} H_{(\bar{a}+0.5)}}^{\text {total }}=n_{C_{\bar{a}} S A_{b} H_{(\bar{a}+1.5)}}^{\text {total }} M_{C_{\bar{a}} S A_{b} H_{(\bar{a}+0.5)}} \text {, etc. }
\end{aligned}
$$

Table 2 lists the way all OPC hydration products molar amounts $\left(n_{\mathrm{C}_{1.7} \mathrm{SH}_{3.2}}^{\mathrm{OPC}}, n_{\mathrm{C}_{6} \mathrm{AS}_{3} \mathrm{H}_{12}}^{\mathrm{OPC}}\right.$, etc., Eqs. $\left.(2.1)-(2.6)\right)$ that can be computed from the initial OPC composition.

Therefore, the total sample mass in the case of OPC hydrated pastes (HCP1-HCP3) will be computed as follows:

$$
\begin{aligned}
m_{\mathrm{spl}}^{\mathrm{OPC}}= & m_{\mathrm{C}_{1.7} \mathrm{~S} \mathrm{OH}_{2.1}}^{\mathrm{OPC}}+m_{\mathrm{C}_{4} \mathrm{AS} \overline{\mathrm{S}}_{10}}^{\mathrm{OPC}}+m_{\mathrm{C}_{6} \mathrm{AFS}_{2} \mathrm{H}_{8}}^{\mathrm{OPC}}+m_{\mathrm{C}_{6} \mathrm{AS}_{3} \mathrm{H}_{12}}^{\mathrm{OPC}}+m_{\mathrm{C}_{4} \mathrm{AH} H_{13}}^{\mathrm{OPC}} \\
& +m_{\mathrm{CH}}^{\mathrm{OPC}}+(1-\alpha)\left(b_{0}^{\mathrm{OPC}}-m_{\mathrm{UO}}^{\mathrm{OPC}}\right)+m_{\mathrm{UO}}^{\mathrm{OPC}}
\end{aligned}
$$


Table 3

Molar relations between the amounts of hydration products and the oxide composition of slag in slag-blended cements [13,14], as described in Section 2.2.

$$
\begin{aligned}
& n_{\mathrm{C}_{4} \mathrm{AS} \mathrm{H}_{14}}^{\mathrm{sl}}=n_{\mathrm{C}_{4} \mathrm{AH}_{22}}^{\mathrm{OPC}}+\left(\gamma \cdot n_{\overline{\mathrm{s}}}^{\mathrm{sl}}-n_{\mathrm{C}_{4} \mathrm{AP}}^{\mathrm{OPC}}\right)=\gamma \cdot n_{\overline{\mathrm{S}}}^{\mathrm{sl}} \\
& n_{\mathrm{C}_{\mathrm{a}} \mathrm{SA}_{\mathrm{b}} \mathrm{H}_{(\mathrm{a}+1.5)}}^{\mathrm{Ol}}=\gamma \cdot n_{\mathrm{s}}^{\mathrm{sl}} \\
& n_{\mathrm{M}_{5} \mathrm{AH}_{13}}^{\mathrm{sl}}=\gamma \cdot \frac{n_{\mathrm{M}}^{\mathrm{sl}}}{\mathrm{s}} \\
& n_{\mathrm{C}_{6} \mathrm{AFS}_{2} \mathrm{H}_{8}}^{\mathrm{sl}}=\gamma \cdot n_{\mathrm{F}}^{\mathrm{sl}} \\
& n_{\mathrm{A}}^{*}=\gamma \cdot n_{\mathrm{A}}^{\mathrm{sl}}-n_{\mathrm{M}_{5} \mathrm{AH}_{13}}^{\mathrm{sl}}-n_{\mathrm{C}_{6} \mathrm{AFS}_{2} \mathrm{H}_{8}}^{\mathrm{sl}}-\left(\gamma \cdot n_{\mathrm{s}}^{\mathrm{sl}}-n_{\mathrm{HO}-\mathrm{AFm}}^{\mathrm{OPC}}\right) \\
& n_{\mathrm{C}_{4} \mathrm{AH}_{22}}^{\mathrm{sl}}=n_{\mathrm{A}}^{*}-\gamma \cdot n_{\mathrm{S}}^{\mathrm{sl}}+\mathrm{b}, \mathrm{b}=\frac{\mathrm{A}}{\mathrm{S}} \text { in } \mathrm{C}_{\overline{\mathrm{a}}} \mathrm{SA}_{\mathrm{b}} \mathrm{H}_{(\overline{\mathrm{a}}+1.5)}
\end{aligned}
$$

\section{Table 4}

Final molar amounts of hydration products in slag-blended cements after the hydration of both the OPC and the slag component, as described in Section 2.3.

$$
\begin{aligned}
& n_{\mathrm{C}_{4} \mathrm{~A} \overline{\mathrm{S}} \mathrm{H}_{14}}^{\text {total }}=n_{\mathrm{C}_{4} \mathrm{~A} \overline{\mathrm{S}} \mathrm{H}_{14}}^{\mathrm{OOC}}+n_{\mathrm{C}_{4} \mathrm{AS} \mathrm{S}_{14}}^{\mathrm{sl}} \\
& n_{\mathrm{C}_{4} \mathrm{AH} \mathrm{H}_{22}}^{\text {tota }}=n_{\mathrm{C}_{4} \mathrm{AH}_{22}}^{\mathrm{sl}} \\
& n_{\mathrm{C}_{\overline{\mathrm{a}}} \mathrm{SA}_{\overline{\mathrm{b}}} \mathrm{H}_{(\overline{\mathrm{a}}+1.5)}}^{\text {tota }}=n_{\mathrm{S}}^{\mathrm{sl}}+n_{\mathrm{C}_{1.7} \mathrm{SH}_{3.2}}^{\mathrm{OPC}} \\
& n_{\mathrm{CH}}^{\text {final }}=n_{\mathrm{CH}}^{\mathrm{OPC}}-\left[\left(n_{\mathrm{S}}^{\mathrm{Sl}}-n_{\mathrm{C}_{4} \mathrm{AH}}^{\mathrm{OPC}}\right) \cdot 4+6 n_{\mathrm{C}_{6} \mathrm{AFS}_{2} \mathrm{H}_{8}}^{\mathrm{OPl}}+\mathrm{a} \cdot n_{\mathrm{S}}^{\mathrm{sl}}+4 \cdot n_{\mathrm{C}_{4} \mathrm{AH}_{22}}^{\mathrm{sl}}-n_{\mathrm{C}}^{\mathrm{sl}}\right]
\end{aligned}
$$

\begin{tabular}{|c|c|c|c|}
\hline \multicolumn{2}{|c|}{$\begin{array}{l}\text { Saturated state } \\
\text { (100\% r.h.) }\end{array}$} & \multicolumn{2}{|c|}{$\begin{array}{l}\text { Dried state } \\
\text { (11\% r.h.) }\end{array}$} \\
\hline Formula & $(\mathrm{g} / \mathrm{mol})$ & Formula & $(\mathrm{g} / \mathrm{mol})$ \\
\hline $\mathrm{C}_{6} \mathrm{~A}_{\mathrm{S}_{3}} \mathrm{H}_{36}$ & 1327.34 & $\mathrm{C}_{6} \mathrm{~A} \overline{\mathrm{S}}_{3} \mathrm{H}_{12}$ & 894.98 \\
\hline $\mathrm{C}_{4} \mathrm{AH}_{22}$ & 722.72 & $\mathrm{C}_{4} \mathrm{AH}_{13}$ & 560.58 \\
\hline $\mathrm{C}_{1.7} \mathrm{SH}_{3.2}$ & 213.09 & $\mathrm{C}_{1.7} \mathrm{SH}_{2.1}$ & 193.27 \\
\hline $\mathrm{CH}$ & 74.00 & $\mathrm{CH}$ & 74.00 \\
\hline $\mathrm{C}_{6} \mathrm{AFS}_{2} \mathrm{H}_{18}$ & 1042.67 & $\mathrm{C}_{6} \mathrm{AFS}_{2} \mathrm{H}_{8}$ & 862.47 \\
\hline $\mathrm{C}_{4} \mathrm{~A} \overline{\mathrm{S}} \mathrm{H}_{14}$ & 658.62 & $\mathrm{C}_{4} \mathrm{~A} \overline{\mathrm{S}} \mathrm{H}_{10}$ & 586.56 \\
\hline $\mathrm{M}_{5} \mathrm{AH}_{19}$ & 645.50 & $\mathrm{M}_{5} \mathrm{AH}_{7}$ & 429.50 \\
\hline
\end{tabular}

\section{Table 5}

Formula and molecular mass for each hydration product formed in saturated state and after drying at $11 \%$ r.h. [10-12,21].

where $b_{0}^{\mathrm{OPC}}$ is the initial OPC mass and it reads:

$b_{0}^{\mathrm{OPC}}=m_{\mathrm{C}_{3} \mathrm{~S}}+m_{\mathrm{C}_{2} \mathrm{~S}}+m_{\mathrm{C}_{3} \mathrm{~A}}+m_{\mathrm{C}_{4} \mathrm{AF}}+m_{\mathrm{C} \overline{\mathrm{S}}}+m_{\mathrm{UO}}^{\mathrm{OPC}}$

The total mass of binder (OPC and slag) $b_{0}$ and thus the mass fractions of the two components, $x^{\mathrm{OPC}}$ and $x^{\mathrm{sl}}$, respectively, can be considered as

$b_{0}=b_{0}^{\mathrm{OPC}}+b_{0}^{\mathrm{sl}}$

$x^{\mathrm{OPC}}=\frac{b_{0}^{\mathrm{OPC}}}{b_{0}}, \quad x^{\mathrm{sl}}=\frac{b_{0}^{\mathrm{sl}}}{b_{0}}$

The term $m_{\mathrm{UO}}$ refers to the unreacted oxides that are part of the composition of OPC besides the considered minerals, and $\alpha$ is the degree of hydration of OPC.

The degree of hydration of the OPC component will be the same as selected in [1], because all the samples are identical (in terms of composition, $w_{0} / b_{0}$ ratio, curing age and conditions, etc.).

\subsection{The hydration of the slag component}

A general equation describing the hydration of the slag component in OPC-slag blended cements is shown in Table 1 (Eq. (1.8)). The hydration products considered in this model are a Mg-containing phase $\left(\mathrm{M}_{5} \mathrm{AH}_{19}\right.$ in saturated state), a Fe-containing phase $\left(\mathrm{C}_{6} \mathrm{AFS}_{2} \mathrm{H}_{18}\right.$, in order to maintain the saturated state considered in the OPC model), the same two AFm phases (HO-AFm, $\mathrm{C}_{4} \mathrm{AH}_{10}$ and $\mathrm{SO}_{4}-\mathrm{AFm}, \mathrm{C}_{4} \mathrm{~A} \overline{\mathrm{S}} \mathrm{H}_{14}$ ) considered for OPC hydration and $\mathrm{C}-\mathrm{S}-\mathrm{H}$ with a lower $C / S$ ratio than the one formed by plain OPC and with a limited Al substitution. This model is based on the one presented by Chen and Brouwers $[13,14]$, and modified in order to take into account newer findings from literature [15-18], which are detailed below. The fate of $\mathrm{Mn}$ in the slag hydration will not be considered in this study, for a number of reasons. Firstly, the model in $[13,14]$ does not account for the contribution of manganese. Secondly, the oxidation state in which $\mathrm{Mn}$ is contained in the slag $\left(\mathrm{Mn}^{2+}\right.$ as $\mathrm{MnO}$ or solid solutions (Fe, Mg,Mn)O [22] etc. or $\mathrm{Mn}^{3+}$ as $\mathrm{Mn}_{2} \mathrm{O}_{3}$ or a $\mathrm{C}_{4} \mathrm{AMn}$ phase [23] or brownmillerite solid solutions [24]) is not known, so its hydration products cannot be predicted with any degree of accuracy.

An important observation to be made is that the formation of an AFt phase is not considered here. Recent studies [15-18] have shown that the amount of ettringite decreases with the increase of the amount of slag in the blended cement. Moreover, in $[16,17]$ no ettringite was found in the samples after 90 days of curing in samples containing $75 \%$ and $90 \%$ slag [17] or $60 \%$ slag [16]. Therefore, in this model all sulphates present in the slag are considered to react with the alumina in the slag to form monosulphate. This reaction, together with the formation of the Fe-containing hydrogarnet, is considered to take priority over the other reaction involving the aluminates (molar relations are presented in Table 2).

It has also been observed that the $\mathrm{C} / \mathrm{S}$ ratio of the formed $\mathrm{C}-\mathrm{S}-\mathrm{H}$ decreases as the proportion of slag in the mix increases $[15,19,20]$. Based on the data presented in [15], the following relation was fitted between the $\mathrm{C} / \mathrm{S}$ ratio of the slag $\mathrm{C}-\mathrm{S}-\mathrm{A}-\mathrm{H}$, referred to as a, and slag content $\left(x^{\text {sl }}\right)$ in the mix:

$\mathrm{a}=1.7-0.5 \cdot x^{\mathrm{sl}}$

The alumina from slag still available for hydration after the formation of monosulphate and hydrogarnet (Eq. (3.5) in Table 3) can afterwards enter the composition of $\mathrm{C}-\mathrm{S}-\mathrm{H}$ (Eq. (7) below and Eq. (3.2) from Table 3 ) and, if a sufficient quantity still remains, form HO-AFm (Eq. (3.6) in Table 3).

$$
\begin{aligned}
n_{\mathrm{A}}^{*} \mathrm{~A} & +n_{\mathrm{C}_{\mathrm{a}} \mathrm{SH}_{(\mathrm{a}+1.5)}^{\text {total }}} \mathrm{C}_{\mathrm{a}} \mathrm{SH}_{(\mathrm{a}+1.5)}+4 \cdot\left(n_{\mathrm{A}}^{*}-\mathrm{b} \cdot n_{\mathrm{C}_{\mathrm{a}} \mathrm{SH}_{(\mathrm{a}+1.5)}^{\text {total }}}\right) \mathrm{CH} \\
& +18 \cdot\left(n_{\mathrm{A}}^{*}-\mathrm{b} \cdot n_{\mathrm{C}_{\mathrm{a}} \mathrm{SH}_{(\mathrm{a}+1.5)}^{\text {total }}}^{*}\right) \mathrm{H} \rightarrow n_{\mathrm{C}_{\mathrm{a}} \mathrm{SA}_{\mathrm{b}} \mathrm{H}_{(\mathrm{a}+1.5)}}^{\text {total }} \mathrm{C}_{\mathrm{a}} \mathrm{SA}_{\mathrm{b}} \mathrm{H}_{(\mathrm{a}+1.5)} \\
& +\left(n_{\mathrm{A}}^{*}-\mathrm{b} \cdot n_{\mathrm{C}_{\mathrm{a}} \mathrm{SH}_{(\mathrm{a}+1.5)}^{\text {total }}}\right) \mathrm{C}_{4} \mathrm{AH}_{22}
\end{aligned}
$$

Furthermore, it is known $[13-15,19,20]$ that there is a relationship between the $\mathrm{C} / \mathrm{S}$ and $\mathrm{A} / \mathrm{S}$ ratios of slag-generated $\mathrm{C}-\mathrm{S}-\mathrm{A}-\mathrm{H}$. Therefore, the maximum A/S ratio of the final hydrated paste will be computed using a linear relationship [13,14,25], if the remaining alumina allows:

$\mathrm{b}=\frac{1-0.4277 \cdot \mathrm{a}}{4.672}$

A factor which largely influences the amounts of hydration products formed, as well as the $\mathrm{C} / \mathrm{S}$ and $\mathrm{A} / \mathrm{S}$ ratios, is the degree of hydration of the slag, $\gamma$. Lumley et al. [26] studied the hydration degree of various slag-OPC hardened cement pastes up to a year of curing, with $w_{0} / b_{0}$ ratios between 0.3 and 0.8 and slag/OPC ratios between 0 and 0.92 . Taking the obtained values into consideration, as well as the age, slag content and $w_{0} / b_{0}$ ratio of each hydrated sample in this study, a degree of hydration was assigned to the slag component (Table 6).

In the case of these "slag only" samples (D1-D5), their mass can be computed using the following relation:

$$
\begin{aligned}
& m_{\mathrm{spl}}^{\mathrm{sl}}=m_{\mathrm{C}_{\mathrm{a}} \mathrm{SA}_{\mathrm{b}} \mathrm{H}_{(\mathrm{a}+0.5)}}^{\mathrm{sl}}+m_{\mathrm{C}_{4} \mathrm{~A} \overline{\mathrm{S}} \mathrm{H}_{10}}^{\mathrm{sl}}+m_{\mathrm{C}_{6} \mathrm{AFS}_{2} \mathrm{H}_{8}}^{\mathrm{sl}}+m_{\mathrm{C}_{4} \mathrm{AH}_{13}}^{\mathrm{sl}}+m_{\mathrm{M}_{5} \mathrm{AH}_{7}}^{\mathrm{sl}} \\
& +(1-\gamma)\left(b_{0}^{\mathrm{sl}}-m_{\mathrm{UO}}^{\mathrm{sl}}\right)+m_{\mathrm{UO}}^{\mathrm{sl}}
\end{aligned}
$$


Table 3 lists the way all slag hydration products molar amounts $\left(n_{\mathrm{C}_{\mathrm{a}} \mathrm{SA}_{\mathrm{b}} \mathrm{H}_{(\mathrm{a}+0.5)}}^{\mathrm{s}}, n_{\mathrm{C}_{4} \mathrm{AS} \mathrm{S}_{10}}^{\mathrm{sl}}\right.$, etc., Eqs. (3.1)-(3.5)) that can be computed from the initial slag composition.

\subsection{The hydration of slag-blended cements}

\subsubsection{The equilibrium of AFm phases}

A first observation to be made is that, in the case of the hydration of the aluminate phases, there is no structural difference depending on whether the hydration product has been generated by the OPC or the slag component. However, as explained in [1], the $\mathrm{HO}-\mathrm{AFm}$ phase is readily transformed to monosulfate $\left(\mathrm{SO}_{4}{ }^{-}\right.$ $\mathrm{AFm}$ ) in the presence of sulphates [27]. In the hydration model of OPC [1], the HO-AFm phase is formed only after depletion of sulphates. Therefore, when adding slag to the binder mix, the sulphate content of slag (assuming all sulphur in the slag to be in sulphate form) is considered to first transform the already existent HO$\mathrm{AFm}$ (because of the faster hydration of OPC) to $\mathrm{SO}_{4}-\mathrm{AFm}$. In this study, all $\mathrm{Mg}$ is considered to be bound into hydrotalcite, and therefore all Al needed for this reaction will be deducted from the $\mathrm{Al}$ available to form AFm phases (Table 3). The equilibrium between hydrotalcite and AFm formation is studied more in depth in $[28,29]$.

\subsubsection{The equilibrium of the $C-S-A-H$ phase}

In the case of the $\mathrm{C}-\mathrm{S}-\mathrm{A}-\mathrm{H}$ phase, its composition will reach an equilibrium between the composition of the slag-generated $\mathrm{C}-\mathrm{S}-$ $\mathrm{A}-\mathrm{H}$ and the OPC-generated one. Therefore, overall $\mathrm{C} / \mathrm{S}$ and $\mathrm{A} / \mathrm{S}$ ratios need to be computed. The value for the overall $\mathrm{C} / \mathrm{S}$ ratio of $\mathrm{C}-\mathrm{S}-\mathrm{A}-\mathrm{H}$, formed by both the OPC and slag components of the blended cement can be computed as follows:

$\overline{\mathrm{a}}=\frac{1.7 \cdot n_{\mathrm{C}_{1.7}}^{\mathrm{OPC}} \mathrm{SH}_{3.2}+\mathrm{a} \cdot n_{\mathrm{s}}^{\mathrm{sl}}}{n_{\mathrm{C}_{1.7} \mathrm{SH}_{3.2}}^{\mathrm{OPC}}+n_{\mathrm{s}}^{\mathrm{sl}}}$

while the A/S ratio, an average $\bar{b}$, can be computed by substituting Eq. (10) into Eq. (8).

In case of insufficient alumina, the $\mathrm{A} / \mathrm{S}$ ratio will be computed using the following equation:

$\overline{\mathrm{b}}=\frac{n_{\mathrm{A}}^{*}}{n_{\mathrm{C}_{1.7} \mathrm{OH}_{3.2}}^{\mathrm{OPC}}+n_{\mathrm{S}}^{\mathrm{sl}}}$

and the relations in Tables 2 and 3. Therefore, $\mathrm{C}_{\overline{\mathrm{a}}} \mathrm{SA}_{\mathrm{b}} \mathrm{H}_{(\overline{\mathrm{a}}+1.5)}$ would describe the composition of the global $\mathrm{C}-\mathrm{S}-\mathrm{A}-\mathrm{H}$ phase.
In the case of these slag-blended hardened pastes (S1-S5), the mass of sample can be computed as follows:

$m_{\mathrm{spl}}=m_{\mathrm{spl}}^{\mathrm{OPC}} \cdot x^{\mathrm{OPC}}+m_{\mathrm{spl}}^{\mathrm{sl}} \cdot x^{\mathrm{sl}}$

\section{Chloride binding of the slag-blended cement pastes}

\subsection{Binding isotherms}

In the case of slag blended cements, the chloride binding ability will be due to the same hydration products as in the case of OPC. However, due to the differences in hydration, a number of changes will occur. The chloride binding of slag-blended hardened cement pastes will depend on three components: the chloride binding abilities of the OPC hydration products and of the slag hydration products, as well as the interaction between these two, which will result in a number of changes from the model presented in [1].

\subsection{Chloride binding - experimental data used in this study}

The experimental results have been selected from [6]. The oxide compositions of the OPC and the slag used can be found in Table 7 . In total 8 samples have been analysed - three hardened cement pastes (pure OPC) and five slag-blended cement hydrates pastes, with a slag content between $25 \%$ and $50 \%$, and having various $w_{0} / b_{0}$ ratios and curing ages. The composition of these samples and their computed sample masses and the attributed degree of hydration (both for the OPC component, $\alpha$ and the slag component, $\gamma$ ) can be found in Tables 6 and 7. Also in Table 6 the parameters of the fitted chloride binding Freundlich isotherms, $\alpha_{F}$ and $\beta_{F}$ are listed. Figs. 1 and 2 show the experimentally obtained chloride binding isotherms [6] for four slag-blended cement samples considered and two OPC pastes are included, split based on their $w_{0} /$ $b_{0}$ ratio. All the shown samples have the same curing age of 2 months before being exposed to the external chlorides. Fig. 1 shows three chloride binding isotherms of pastes with a $w_{0} / b_{0}$ of 0.3 and slag contents of 0\% (HCP1), 25\% (S1) and 40\% (S4). As expected, the chloride binding capacity increases with the increase of the slag content (Section 1). The same trend can be seen in Fig. 2 , which presents three chloride binding isotherms of pastes with a $w_{0} / b_{0}$ of 0.5 and slag contents of $0 \%$ (HCP2), 25\% (S2) and 50\% (S5). When comparing the two figures (for instance the S1 and $\mathrm{S} 2$ isotherms), it can be observed that the $w_{0} / b_{0}$ ratio, and implicitly the degree of hydration, has a large influence on the chloride

Table 6

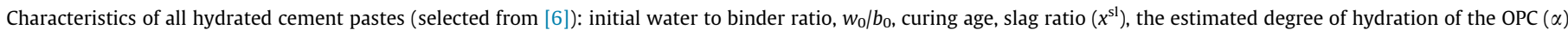

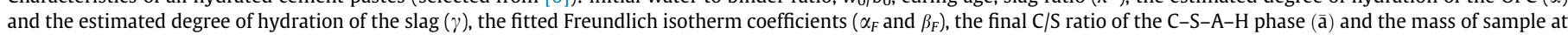
$11 \%$ r.h. ( $\left.m_{\text {spl }}\right)$, computed using Eqs. (2), (9), and (12)).

\begin{tabular}{|c|c|c|c|c|c|c|c|c|c|}
\hline & $w_{0} / b_{0}$ & $\begin{array}{l}\text { Age } \\
\text { (months) }\end{array}$ & $x^{51}$ & $\alpha$ & $\gamma$ & $\alpha_{F}$ & $\beta_{F}$ & $\overline{\mathrm{a}}$ & $\begin{array}{l}m_{\mathrm{spl}} \\
(\mathrm{g})\end{array}$ \\
\hline HCP1 & 0.3 & 2 & 0 & 0.75 & - & $\begin{array}{l}6.92 \\
7.42\end{array}$ & $\begin{array}{l}0.359 \\
0.372\end{array}$ & 1.70 & 113.49 \\
\hline HCP2 & 0.5 & 2 & 0 & 0.80 & - & $\begin{array}{l}7.72 \\
7.49 \\
7.44\end{array}$ & $\begin{array}{l}0.414 \\
0.417 \\
0.396\end{array}$ & 1.70 & 114.39 \\
\hline НСР3 & 0.5 & 9 & 0 & 0.85 & - & $\begin{array}{l}7.28 \\
7.29\end{array}$ & $\begin{array}{l}0.443 \\
0.409\end{array}$ & 1.70 & 115.28 \\
\hline $\mathrm{S} 1$ & 0.3 & 2 & 0.25 & 0.75 & 0.60 & $\begin{array}{l}7.25 \\
7.29\end{array}$ & $\begin{array}{l}0.363 \\
0.362\end{array}$ & 1.58 & 109.13 \\
\hline S2 & 0.5 & 2 & 0.25 & 0.80 & 0.70 & 10.23 & 0.411 & 1.58 & 109.43 \\
\hline S3 & 0.5 & 9 & 0.25 & 0.85 & 0.75 & 9.36 & 0.486 & 1.58 & 109.36 \\
\hline S4 & 0.3 & 2 & 0.40 & 0.75 & 0.55 & 7.83 & 0.396 & 1.50 & 109.88 \\
\hline S5 & 0.5 & 2 & 0.50 & 0.80 & 0.50 & 9.94 & 0.495 & 1.45 & 110.70 \\
\hline
\end{tabular}


Table 7

Oxide composition and LOI of the OPC and slag considered in this study, from [6].

\begin{tabular}{lcc}
\hline & $\begin{array}{l}\text { OPC } \\
\text { (\%mass) }\end{array}$ & $\begin{array}{l}\text { Slag } \\
\text { (\%mass) }\end{array}$ \\
\hline $\mathrm{CaO}$ & 63.58 & 35.49 \\
$\mathrm{SiO}_{2}$ & 21.26 & 36.18 \\
$\mathrm{Al}_{2} \mathrm{O}_{3}$ & 4.09 & 10.02 \\
$\mathrm{Fe}_{2} \mathrm{O}_{3}$ & 2.89 & 0.50 \\
$\mathrm{SO}_{3}$ & 2.79 & 1.51 \\
$\mathrm{MgO}_{\mathrm{Na}} \mathrm{O}$ & 2.47 & 0.66 \\
$\mathrm{~K}_{2} \mathrm{O}$ & 0.58 & 0.77 \\
$\mathrm{Mn}_{2} \mathrm{O}_{3}$ & 0.62 & 0.50 \\
$\mathrm{SrO}_{\mathrm{TiO}}$ & 0.06 & 13.58 \\
$\mathrm{P}_{2} \mathrm{O}_{5}$ & 0.12 & 0.04 \\
$\mathrm{RO}_{\mathrm{LOI}}$ & 0.20 & 0.67 \\
$\mathrm{LO}$ & 0.07 & 0.01 \\
\hline
\end{tabular}

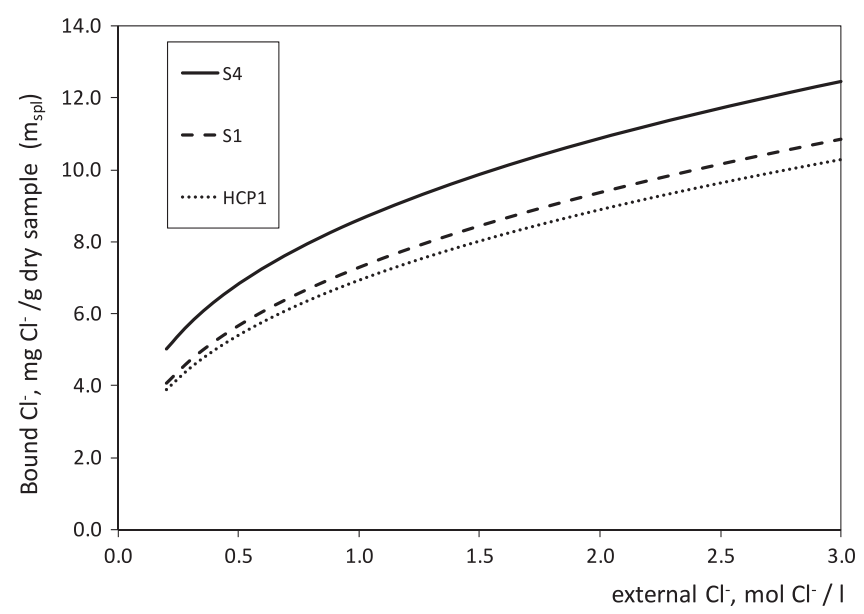

Fig. 1. Experimental isotherms used in this study, selected for hydrated cement pastes with $w_{0} / b_{0} 0.3[6]$. The composition of all samples (HCP1: 0\% slag, S1: $25 \%$ slag and S4: $40 \%$ slag) can be found in Table 6.

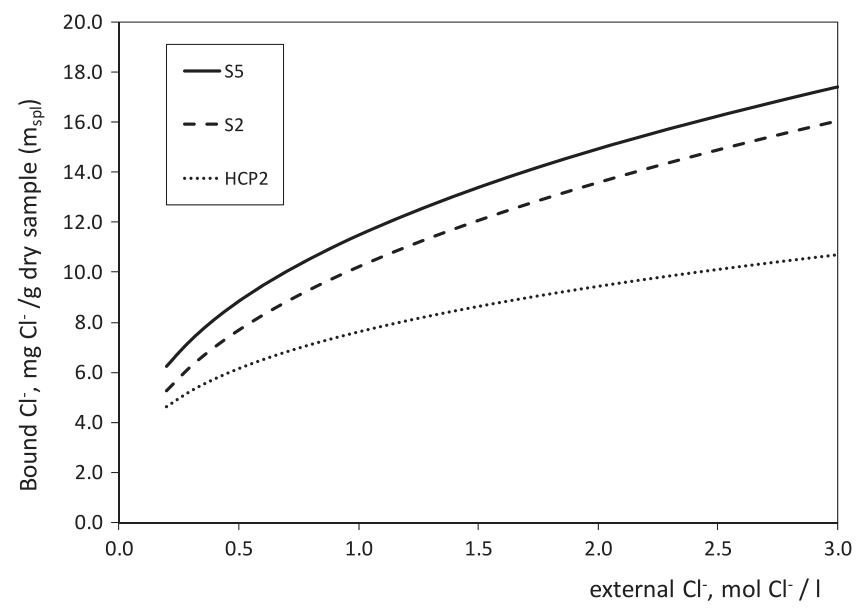

Fig. 2. Experimental isotherms used in this study, selected for hydrated cement pastes with $w_{0} / b_{0} 0.5$ [6]. The composition of all samples (HCP2: 0\% slag, S2: $25 \%$ slag and S5: $50 \%$ slag) can be found in Table 6.

binding capacity, which underlines the importance of taking into account such parameters as $w_{0} / b_{0}$ ratio, age of the sample, curing conditions etc. when evaluating chloride binding.

\section{The chloride binding ability of slag-blended cement hydration products}

The chloride binding isotherms in this study will be termed either $\mathrm{C}_{\mathrm{b}, \mathrm{hp}}^{0}$ for chloride binding abilities expressed in $\mathrm{mg} \mathrm{Cl} \mathrm{Cl}^{-} / \mathrm{g}$ hydration product conditioned to $11 \%$ r.h., or $C_{b \text {,hp }}$ for the chloride binding capacities expressed in $\mathrm{mg} \mathrm{Cl}^{-} / \mathrm{g}$ sample at $11 \%$ r.h., $m_{\text {spl }}$, as also employed in [1]. The term $n_{\mathrm{hp}}$ refers to the molar amount of the specified hydration product, in moles, calculated using Tables $2-4$. The mass of sample in grams at $11 \%$ r.h., $m_{\text {spl }}$, is computed as explained in Section 2.1. The following equation details the general relation between $C_{b, h p}^{0}$ and $C_{b, h p}$ :

$\mathrm{C}_{\mathrm{b}, \mathrm{hp}}=\mathrm{C}_{\mathrm{b}, \mathrm{hp}}^{0} \cdot \frac{n_{\mathrm{hp}} \cdot \mathrm{M}_{11 \% \mathrm{rh.hp}}}{m_{\mathrm{spl}}}$

The three component chloride bindings (see Section 5) can be computed using the molar amounts in Tables $2-4$ for $\mathrm{C}_{\mathrm{b}}^{\mathrm{OPC}}, \mathrm{C}_{\mathrm{b}}^{\mathrm{sl}}$ and $\mathrm{C}_{\mathrm{b}}^{\text {total }}$, respectively, the molecular masses from Table 5 and the mass of sample $m_{\text {spl }}$ from Table 6 .

The chloride concentration of the external solution, $c$, is always expressed in $\mathrm{mol} \mathrm{Cl}^{-} / 1$ solution and considered to be in equilibrium with the pore solution. Therefore, the terms of "external", "free" or "equilibrium" chloride concentration will be used interchangeably throughout this study.

\subsection{Chloride binding capacity of the aluminate phases in slag-blended cements}

Firstly, the chloride binding of the aluminate phases will be considered to be described by the same equations detailed in [1]. The "simplified version" of this model will be used, which does not take into consideration the contribution of $\mathrm{CH}$ and FS (Friedel's salt, $3 \mathrm{CaO} \cdot \mathrm{Al}_{2} \mathrm{O}_{3} \cdot \mathrm{CaCl}_{2} \cdot 10 \mathrm{H}_{2} \mathrm{O}$ ) to the physical binding of chlorides. The reason for this choice is the low contribution of these two phases found in [1] (around 3\% of the total bound chlorides), as well as ease of use. Moreover, the surface binding of chlorides by these two hydrates is controversial, and no data about their binding capacities in systems where hydrates with more negative surfaces ( $\mathrm{C}-\mathrm{S}-\mathrm{A}-\mathrm{H}$ with various $\mathrm{C} / \mathrm{S}$ ratios, see following section) coexist. Another difference from the model presented in [1] is that the total amounts of $\mathrm{HO}-\mathrm{AFm}$ and $\mathrm{SO}_{4}-\mathrm{AFm}$ (just as $\mathrm{C}-\mathrm{S}-\mathrm{A}-\mathrm{H}$ ) generated by both the hydration of OPC and the one of the slag (Table 4), will be considered able to bind chlorides. The isotherms describing the chloride binding capacity of $\mathrm{HO}-\mathrm{AFm}$ and $\mathrm{SO}_{4}-\mathrm{AFm}$ from OPC are given in Table 8 (Eqs. (8.2) and (8.1), respectively) and are based on the findings in [30,31], where the Cl-containing phase formed is considered to be Fridel's salt. Another possible phase is Kuzel's salt ( $\left.3 \mathrm{CaO} \cdot \mathrm{Al}_{2} \mathrm{O}_{3} \cdot 1 / 2 \mathrm{CaCl}_{2} \cdot 1 / 2 \mathrm{CaSO}_{4} \cdot 11 \mathrm{H}_{2} \mathrm{O}\right)$ [32], but to the authors' knowledge a chloride binding isotherm for its formation has not been measured in literature.

Another phase which is considered to be able to bind chlorides is hydrotalcite (HT) [28]. However, to the authors' knowledge, a chloride binding isotherm of HT has not been quantified in literature. Kayali et al. [28] present the chloride binding of HT at only one chloride concentration (3\%) and only after $24 \mathrm{~h}$ (compared to the 14 days usually used for obtaining chloride binding isotherms [6]). Another aspect of quantifying the chloride binding capacity of hydrotalcite would be the variation in the $\mathrm{Al}^{3+} /\left(\mathrm{Al}^{3+}+\mathrm{Mg}^{2+}\right)$ ratio of $\mathrm{HT}$, which is known to vary between 0.2 and 0.33 [28].

Moreover, the particular slag considered in this study has a very low $\mathrm{MgO}$ content $(0.66 \%$ by mass of slag, see Table 7 ) compared to the ones cited in literature (up to $12 \%$ by mass in [20], $6.3 \%$ by mass in [28], between $7 \%$ and $13 \%$ by mass in [29]). Therefore, the influence of the chloride binding of HT is minimal in this case and it will not be considered further. 
4.2. Chloride binding capacity of the $C-S-A-H$ phase in slag-blended cements

As explained in Section 2.2, the $\mathrm{C}-\mathrm{S}-\mathrm{A}-\mathrm{H}$ phase generated by slag-blended cements will have two main differences from the one formed by the hydration of pure OPC: the $\mathrm{C} / \mathrm{S}$ ratio and the $\mathrm{A} / \mathrm{S}$ ratio. However, as explained in Section 2.1, the value of 1.7 for the $\mathrm{C} / \mathrm{S}$ ratio, considered for the $\mathrm{C}-\mathrm{S}-\mathrm{H}$ formed through the hydration of OPC in [1], actually corresponds to the $C /(S+A)$ ratio. Therefore, the $\mathrm{C} /(\mathrm{S}+\mathrm{A})$ ratio will be taken into account also for the chloride binding capacity of the $\mathrm{C}-\mathrm{S}-\mathrm{A}-\mathrm{H}$ generated by the slag component.

A modification from the $\mathrm{C}_{\mathrm{b}, \mathrm{C}-\mathrm{S}-\mathrm{A}-\mathrm{H}, \mathrm{OPC}}$ isotherm presented in [1], will be the use of a simplified relation which does not take into account the $C_{2} S / C_{3} S$ ratio in OPC for the slag-generated $\mathrm{C}-\mathrm{S}-\mathrm{A}-\mathrm{H}$ chloride binding capacity. The $\mathrm{C}-\mathrm{S}-\mathrm{H}$ isotherm proposed in [1] was a combination of two isotherms proposed by Zibara [6] for $\mathrm{C}-\mathrm{S}-\mathrm{H}$ formed by $\mathrm{C}_{2} \mathrm{~S}$ and $\mathrm{C}_{3} \mathrm{~S}$, respectively. However (as explained in [1]), there is no structural difference between the final products of hydration. In [1], a combination of the two isotherms was used for the sake of precision. The same isotherm (Eqs. (8.3)-(8.5)) will be used for the chloride binding of $\mathrm{C}-\mathrm{S}-\mathrm{A}-\mathrm{H}$ when referring to the individual hydration of OPC. However, the two isotherms proposed by Zibara [6] are almost identical. Therefore, the following relation was selected to further represent the chloride binding of a C-S-A$\mathrm{H}$ generated by slag:

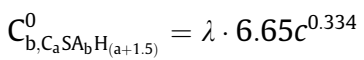

As the selected chloride binding isotherm for $\mathrm{C}-\mathrm{S}-\mathrm{A}-\mathrm{H}$ is valid for a $\mathrm{C} /(\mathrm{S}+\mathrm{A})$ ratio of 1.7 , a correction needs to be done for lower values. Viallis-Terrisse [32] has studied the chloride binding ability of lyophilized C-S-H gels with C/S ratios between 0.65 and 1.50 , using a $\mathrm{NaCl}$ solution with the concentration of $0.5 \mathrm{M}$. The results have shown that when the $\mathrm{C} / \mathrm{S}$ ratio decreases from 1.55 to 1.2 , the amount of bound chlorides increases. When the $\mathrm{C} / \mathrm{S}$ ratio further decreases up to 0.8 , the chloride binding capacity also slightly decreases, the trend accentuating (higher slope of the linear fit) for $\mathrm{C} / \mathrm{S}$ ratios between 0.8 and 0.6 . Due to the use of lyophilized $\mathrm{C}-\mathrm{S}-\mathrm{H}$ gels, the measured amounts of bound chlorides were very different than when using alcohol for drying the gels. Therefore, just the ratio between the bound chlorides amounts is used here, since this is considered to be correct, as a ratio of results that follow the same experimental protocol. Fig. 3 shows these ratios as a function of the $\mathrm{C} / \mathrm{S}$ ratio in $\mathrm{C}-\mathrm{S}-\mathrm{H}$ and the fitted parabolic equation, extrapolated to a $C / S$ ratio of 1.7 , which is considered to have a ratio of unity (this point is also part of the fit and figures as a hollow circle in Fig. 3). The result of this equation will be considered as the coefficient $\lambda$ by which the chloride binding of the $\mathrm{C}-\mathrm{S}-\mathrm{A}-\mathrm{H}$ phase needs to be multiplied in order to account for the differences in their $\mathrm{C} / \mathrm{S}$ ratios. This coefficient will be calculated in the same way for both the OPC-slag blended cement samples, as well as the "slag only" samples.

$\lambda=-2.1381 \cdot\left(\frac{\overline{\mathrm{a}}}{1+\overline{\mathrm{b}}}\right)^{2}+4.6139 \cdot \frac{\overline{\mathrm{a}}}{1+\overline{\mathrm{b}}}-0.6646$

Table 8

Chloride binding isotherms in hydrated slag-blended cement pastes.

$\mathrm{C}_{\mathrm{b}, \mathrm{SO}_{4}-\mathrm{AFm}}^{0}=51.89 c^{0.58}$
$\mathrm{C}_{\mathrm{b}, \mathrm{HO}-\mathrm{AFm}}^{0}=126.5$
$\delta_{\mathrm{C}_{3} \mathrm{~S}}=\frac{m_{\mathrm{C}_{3} \mathrm{~s}}}{m_{\mathrm{C}_{3} \mathrm{~s}+m_{\mathrm{C}_{2} \mathrm{~s}}}}$
$\delta_{\mathrm{C}_{2} \mathrm{~S}}=\frac{m_{\mathrm{C}_{2} \mathrm{~s}}}{m_{\mathrm{C}_{3} \mathrm{~s}}+m_{\mathrm{C}_{2} \mathrm{~s}}}=1-\delta_{\mathrm{C}_{3} \mathrm{~S}}$
$\mathrm{C}_{\mathrm{b}, \mathrm{C}-\mathrm{S}-\mathrm{H}, \mathrm{Z}}^{0}=\lambda \cdot\left(6.65 c^{0.334} \cdot \delta_{\mathrm{C}_{3} \mathrm{~S}}+7.89 c^{0.136} \cdot \delta_{\mathrm{C}_{2} \mathrm{~S}}\right)$

The total amount of chlorides bound by a sample will be termed $C_{b}$ and computed as the sum of the individual chloride binding abilities of $\mathrm{HO}-\mathrm{AFm}, \mathrm{SO}_{4}-\mathrm{AFm}$ and $\mathrm{C}-\mathrm{S}-\mathrm{A}-\mathrm{H}$.

\section{Chloride binding isotherms}

Three types of chloride binding isotherms will be computed in this study - for the individual hydration of OPC (described in Table 2) $\mathrm{C}_{\mathrm{b}}^{\mathrm{OPC}}$, the hydration of the slag component while only the role of $\mathrm{CH}$ produced by the OPC hydration is taken into account (molar amounts from Table 3) $\mathrm{C}_{\mathrm{b}}^{\mathrm{sl}}$ and the total chloride binding of both components $C_{b}^{\text {total }}$ using the amounts in Table 4, respectively. In all three cases, the general formula for the chloride binding capacity of the hydrated paste is expressed by:

$\mathrm{C}_{\mathrm{b}}=\mathrm{C}_{\mathrm{b}, \mathrm{C}-\mathrm{S}-\mathrm{A}-\mathrm{H}}+\mathrm{C}_{\mathrm{b}, \mathrm{SO}_{4}-\mathrm{AFm}}+\mathrm{C}_{\mathrm{b}, \mathrm{HO}-\mathrm{AFm}}$

where the three component chloride bindings can be computed using the molar amounts in Tables $2-4$ for $\mathrm{C}_{\mathrm{b}}^{\mathrm{OPC}}, \mathrm{C}_{\mathrm{b}}^{\mathrm{sl}}$ and $\mathrm{C}_{\mathrm{b}}^{\text {total }}$, respectively.

\subsection{Chloride binding of the slag-blended cement samples}

In this section, the $\mathrm{C}_{\mathrm{b}}^{\text {total }}$ isotherms will be computed for the $\mathrm{S1-}$ S5 samples (composition in Table 6) by computing the individual chloride binding isotherms of $\mathrm{C}-\mathrm{S}-\mathrm{A}-\mathrm{H}, \mathrm{SO}_{4}-\mathrm{AFm}$ and $\mathrm{HO}-\mathrm{AFm}$ as described in Section 4 and using the molar amounts computed in Table 4. In other words, the total amounts of hydration products generated by the hydration of the slag-blended cements will be considered, including their interactions as described in Section 2.3.

Fig. 4 shows how the computed $\mathrm{C}_{\mathrm{b}}^{\text {total }}$ for $\mathrm{S} 4$ (composition from Table 6) compares to the experimental data, as well as the contribution of the $\mathrm{SO}_{4}-\mathrm{AFm}$ and $\mathrm{C}-\mathrm{S}-\mathrm{A}-\mathrm{H}$ phases. In this case, the $\mathrm{C}-\mathrm{S}-\mathrm{A}-\mathrm{H}$ phase contributes about two thirds of the total chloride binding capacity of the paste. Furthermore, these two total contributions are split into their components in order to see the influence of the slag hydration products on the total chloride binding ability of the paste. Figs. 5 and 6 show this breakdown for both the $\mathrm{SO}_{4}-\mathrm{AFm}$ and $\mathrm{C}-\mathrm{S}-\mathrm{A}-\mathrm{H}$ phases, respectively. From Fig. 5 it can be seen that the contribution of the $\mathrm{SO}_{4}-\mathrm{AFm}$ phase determined by the hydration of slag is slightly higher than the one of OPC. This can be explained by the fact that, as explained in Section 4.1 and Table 4, there are two mechanisms considered for the formation of $\mathrm{SO}_{4}-\mathrm{AFm}$ through the hydration of slag, one involving the aluminate phase generated by the dissolving of the

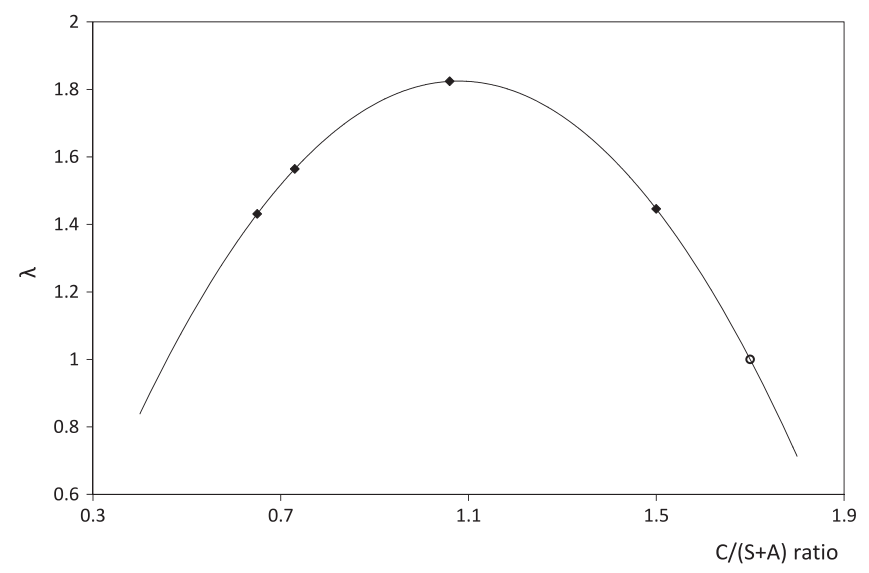

Fig. 3. Correction for the binding capacity of $\mathrm{C}-\mathrm{S}-\mathrm{A}-\mathrm{H}$ as a function of the $\mathrm{C} /(\mathrm{S}+\mathrm{A}$ ratio (Eqs. (15) and (8.5) in Table 8. Black diamonds represent data points from [33] and the hollow circles the points at $\mathrm{C} /(\mathrm{S}+\mathrm{A})=1.7$ and $\lambda=1$. 


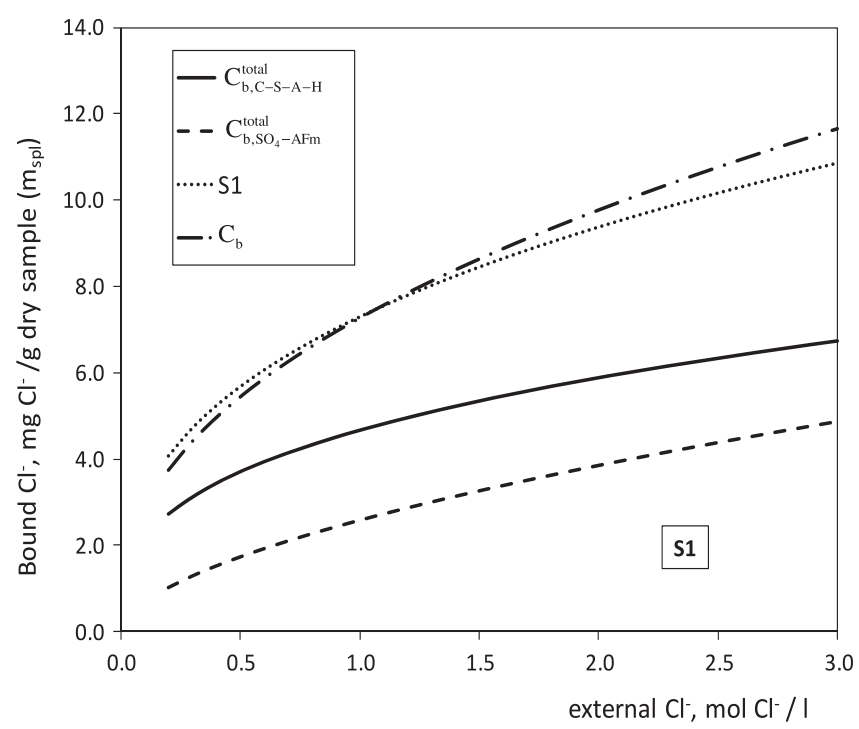

Fig. 4. Chloride binding capacity of hydration products in hydrated slag-blended cement pastes, applied to sample S1 (see Table 6). Isotherms are described in Sections 4 and 5.

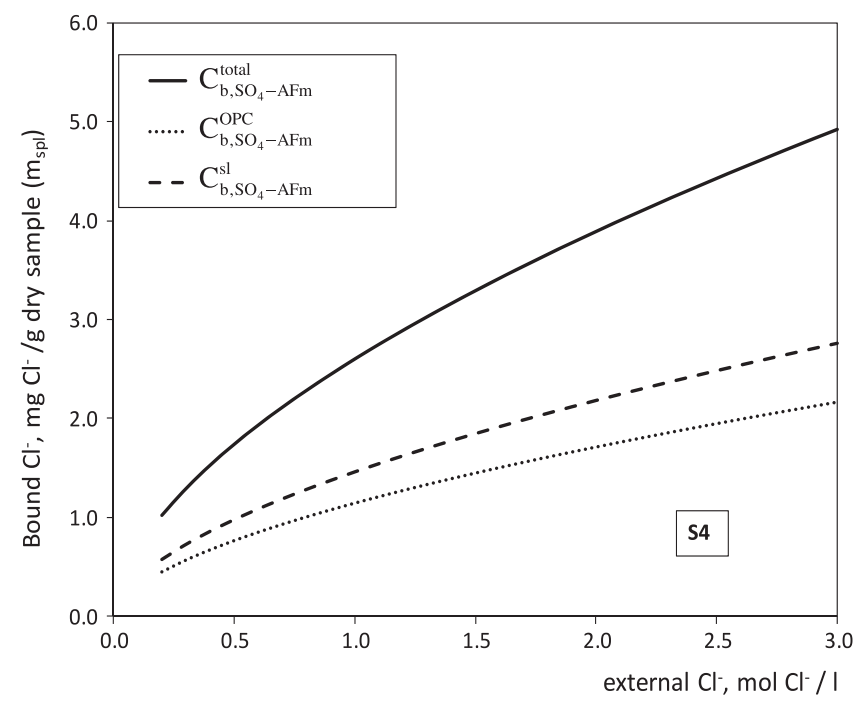

Fig. 5. Chloride binding capacity of the $\mathrm{SO}_{4}-\mathrm{AFm}$ phase in hydrated slag-blended cement pastes, applied to sample S4 (see Table 6). Isotherms are described in Section 4.1.

slag itself, and the second one coming from the conversion of $\mathrm{HO}-\mathrm{AFm}$ generated by the hydration of OPC into $\mathrm{SO}_{4}-\mathrm{AFm}$.

In the case of the $\mathrm{C}-\mathrm{S}-\mathrm{A}-\mathrm{H}$ phase (Fig. 6), the trend is reversed: the contribution of the OPC-generated $\mathrm{C}-\mathrm{S}-\mathrm{A}-\mathrm{H}$ is slightly higher than the one generated by the slag. However, both these isotherms take into consideration the $\lambda$ coefficient (see Eq. (15)), which explains the increase of the $\mathrm{C}-\mathrm{S}-\mathrm{A}-\mathrm{H}$ chloride binding capacity. There is no structural difference between the two $\mathrm{C}-\mathrm{S}-\mathrm{A}-\mathrm{H}$ phases, only the computed amounts are dependent of the $C$ and the $S$ contents of the slag.

Fig. 7 shows the breakdown of chloride binding capacity between the four mentioned phases as a function of the free chloride concentration. As it can be seen, the contribution of the $\mathrm{C}-\mathrm{S}-\mathrm{A}-\mathrm{H}$ phase slightly decreases from a total of $70 \%$ of the bound chlorides (39\% the OPC-generated $\mathrm{C}-\mathrm{S}-\mathrm{A}-\mathrm{H}$ and $31 \%$ the slag-generated one) at $0.5 \mathrm{M}$ external chloride concentration to $63 \%$ at a free chloride concentration of $1.8 \mathrm{M}$ (divided as $35 \%$ the

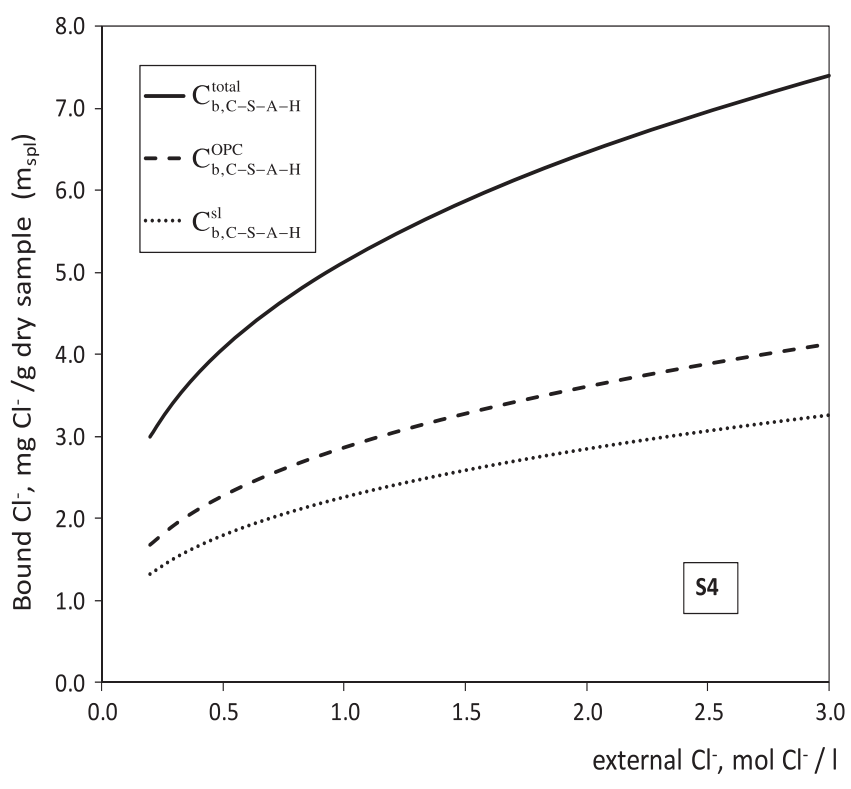

Fig. 6. Chloride binding capacity of the $\mathrm{C}-\mathrm{S}-\mathrm{A}-\mathrm{H}$ phase in hydrated slag-blended cement pastes, applied to sample S4 (see Table 6). Isotherms are described in Section 4.2 .

OPC-generated $\mathrm{C}-\mathrm{S}-\mathrm{A}-\mathrm{H}$ contribution and $28 \%$ the slag-generated amount). On the contrary, the contribution of the $\mathrm{SO}_{4}-\mathrm{AFm}$ phase shows an increase from $30 \%$ of the bound chlorides (13.2\% from the OPC-generated $\mathrm{SO}_{4}-\mathrm{AFm}$ and $16.8 \%$ from the slag hydration) at $0.5 \mathrm{M}$ external chloride concentration to $37 \%$ at a free chloride concentration of $1.8 \mathrm{M}(16.2 \%$ and $20.7 \%$ from the OPC-generated $\mathrm{SO}_{4}-\mathrm{AFm}$ and the slag-generated one, respectively).

\subsection{Evaluation of the contribution of the slag component to chloride binding}

As explained in Section 2.3 and quantified in Table $4, C_{b}^{\text {total }}$ will not simply be a sum of $C_{b}^{O P C}$ and $C_{b}^{s l}$, due to the fact that the hydration of the OPC-component and that of the slag component do not progress independently, as explained in Section 4. Therefore, it can be considered that the chloride binding capacity of slag-blended hydrated pastes consists of three components: one due to the hydration products of OPC remaining unmodified by the slag hydration (so just $\mathrm{SO}_{4}-\mathrm{AFm}$ and $\mathrm{C}-\mathrm{S}-\mathrm{A}-\mathrm{H}$ when the $\lambda$ coefficient is set to unity), one due to the hydration products of the slag while only the role of $\mathrm{CH}$ produced by the OPC hydration is taken into account (actually $\mathrm{C}_{\mathrm{b}}^{\mathrm{sl}}$ ), and one which represents the interaction of the two components of the binder.

In order to quantify this third component, three other equations will be used. The interaction between the OPC and the slag component of the binder can be described in terms relevant to their chloride binding abilities by two phenomena: the decrease of the $\mathrm{C} /$ $(\mathrm{S}+\mathrm{A})$ ratio of $\mathrm{C}-\mathrm{S}-\mathrm{A}-\mathrm{H}$ (so through the $\lambda$ coefficient in Eq. (8.5)) and the consumption of the HO-AFm phase by the sulphate ions generated by slag. Therefore, the $\mathrm{C}_{\mathrm{b}}^{\mathrm{sl}}$ will be compared to the following three isotherms:

$\mathrm{C}_{\mathrm{b}}^{\text {diff }}=\mathrm{C}_{\mathrm{b}}^{\text {exp }, \text { total }}-\mathrm{C}_{\mathrm{b}}^{\mathrm{exp}, \mathrm{OPC}} \cdot x^{\mathrm{OPC}}$

$\mathrm{C}_{\mathrm{b}}^{\text {corr1 }}=\mathrm{C}_{\mathrm{b}}^{\mathrm{diff}}-\mathrm{C}_{\mathrm{b}, \mathrm{C}-\mathrm{S}-\mathrm{A}-\mathrm{H}}^{\mathrm{OPC}} \cdot(\lambda-1)$

$\mathrm{C}_{\mathrm{b}}^{\text {corr2 }}=\mathrm{C}_{\mathrm{b}}^{\mathrm{corr} 1}+\frac{n_{\mathrm{C}_{4} \mathrm{AH}}^{\mathrm{OPC}} \cdot \mathrm{M}_{11 \% \text { r.h.,., } \mathrm{C}_{4} \mathrm{AH}_{22}}}{m_{\mathrm{spl}}}$

$$
\cdot\left(\mathrm{C}_{\mathrm{b}, \mathrm{SO}_{4}-\mathrm{AFm}}^{0}-\mathrm{C}_{\mathrm{b}, \mathrm{HO}-\mathrm{AFm}}^{0}\right)
$$




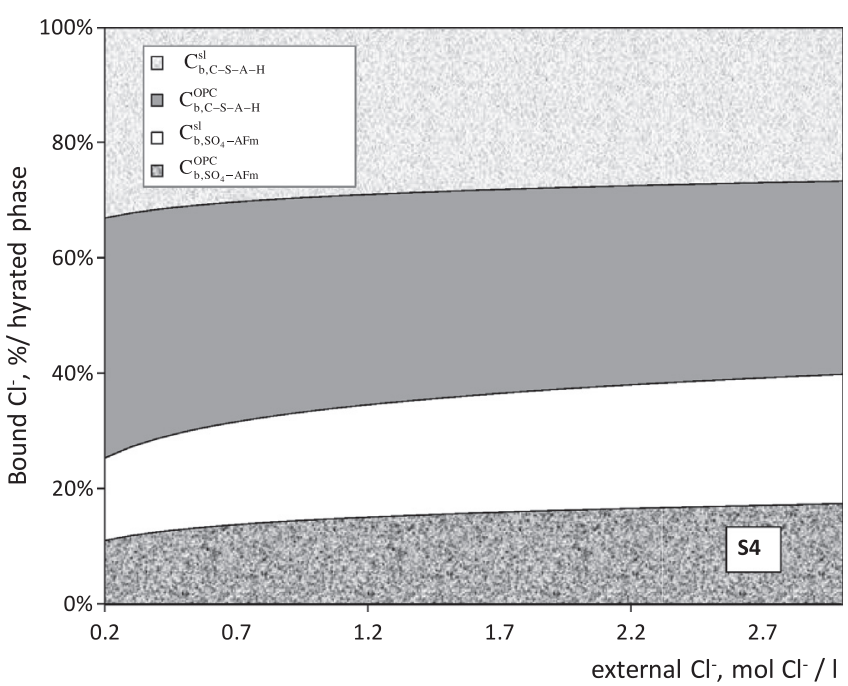

Fig. 7. Breakdown of bound chlorides by hydration products as a function of equilibrium chloride concentration in the pore solution applied to sample S4 (see Table 6). Isotherms are described in Sections 4 and 5.

The isotherm $\mathrm{C}_{\mathrm{b}}^{\text {diff }}$ represents the difference between the total chloride binding ability of the slag-blended hydrated paste and the chloride binding of its OPC component, while taking into account the OPC ratio in the blended cement. If the interactions in Section 2.3 would not be taken into account (so the hydration would be described solely on the basis of Sections 2.1 and 2.2 as two separate processes - the hydration of the OPC-component and that of the slag-component, respectively), the $\mathrm{C}_{\mathrm{b}}^{\text {diff }}$ should be equal to $\mathrm{C}_{\mathrm{b}}^{\mathrm{sl}}$.

Since it has been explained that this approach would be over-simplified, $\mathrm{C}_{\mathrm{b}}^{\text {corr1 }}$ is computed to account for the influence of the decreased $\mathrm{C} / \mathrm{S}$ ratio of the $\mathrm{C}-\mathrm{S}-\mathrm{A}-\mathrm{H}$ of the OPC component (Section 2.3.2). This isotherm considers the fact that the C-S-A$\mathrm{H}$ generated from the OPC hydration has a higher $\mathrm{C} / \mathrm{S}$ ratio and therefore a decreased chloride binding (see Section 4.2) compared to the $\mathrm{C}-\mathrm{S}-\mathrm{A}-\mathrm{H}$ of the slag-blended cement hydration. A correction is therefore applied to $C_{b}^{\text {diff }}$ by subtracting this increase which is due to the $\lambda$ coefficient (see Eq. (8.5)).

The third isotherm, $C_{b}^{\text {corr2 }}$, further accounts for the transformation of $\mathrm{HO}-\mathrm{AFm}$ to $\mathrm{SO}_{4}-\mathrm{AFm}$, as described in Section 2.3.1. In order to achieve this, the contribution of OPC-generated HO-AFm to the chloride binding is subtracted, and instead the influence of the newly-formed $\mathrm{SO}_{4}-\mathrm{AFm}$ is added. The influence of this transformation on the mass of the sample is considered to be negligible. In this way, both interactions considered in Section 2.3 are accounted for, and the contribution of the slag component of the blended cement can be validated by comparing the $\mathrm{C}_{\mathrm{b}}^{\text {corr2 }}$ and $\mathrm{C}_{\mathrm{b}}^{\mathrm{sl}}$ isotherms.

Fig. 8 illustrates the $\mathrm{C}_{\mathrm{b}}^{\text {diff }}, \mathrm{C}_{\mathrm{b}}^{\text {corr1 }}$ and $\mathrm{C}_{\mathrm{b}}^{\text {corr2 }}$ isotherms for the sample $S 4$, together with the $C_{b}^{s l}$ isotherm for comparison. Initially, the difference between the $C_{b}^{\text {diff }}$ and $C_{b}^{s l}$ is quite significant. When $C_{b}^{\text {corr1 }}$ is computed to account for the $\lambda$ coefficient contribution, the difference to $C_{b}^{s l}$ becomes lower. With the introduction of $C_{b}^{\text {corr2 }}$, the match to $C_{b}^{s l}$ becomes very good. Therefore, it can be concluded that, indeed, the interaction between the hydration of the OPC and that of the slag in terms of chloride binding ability can be estimated accurately by the decrease of the $\mathrm{C} /(\mathrm{S}+\mathrm{A})$ ratio of $\mathrm{C}-\mathrm{S}-\mathrm{A}-\mathrm{H}$ and the consumption of the $\mathrm{HO}-\mathrm{AFm}$ phase by the sulphate ions generated by the slag dissolution. Moreover, this match proves that the model works independently for describing the chloride binding ability of the slag component, and also that the model used to quantify the hydration of the slag is valid.

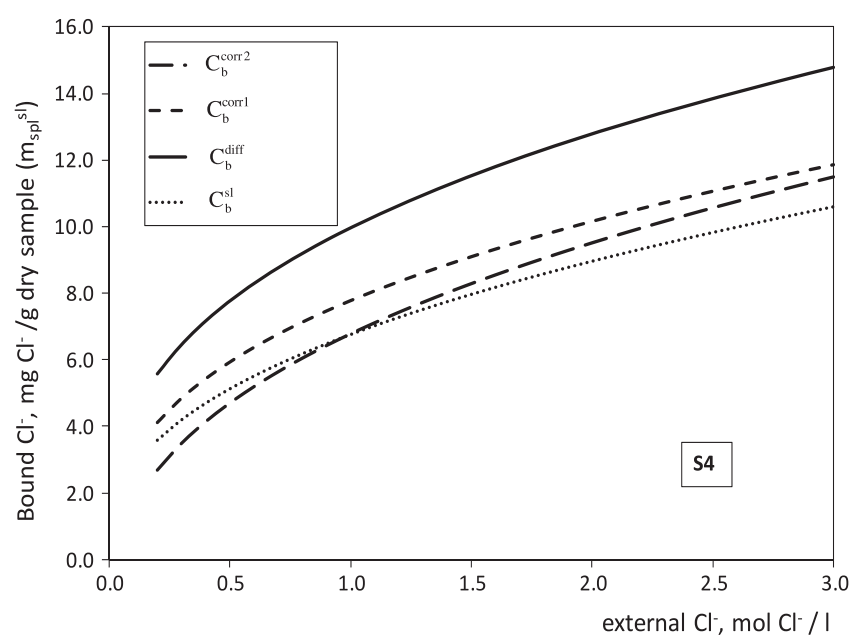

Fig. 8. Chloride binding capacity of the slag component in hydrated slag-blended cement pastes applied to sample S4 (see Table 6). Isotherms are described in Section 5.2.

\section{Comparison with experimental data and other models from literature}

The only non-kinetic chloride binding model which could be found in literature is the one of Dhir et al. [7]. While this model takes into account the slag percentage in the slag-blended cement and the concentration of free chlorides, it does not take into account other parameters such as $w / b_{0}$, curing age etc. Therefore, for the samples S1, S2 and S3, for instance, the prediction will be the same. The equation describing this model is:

$$
\begin{aligned}
\mathrm{C}_{\mathrm{b}}^{\text {Dhir }}= & {\left[-22.21 \cdot\left(x^{\mathrm{sl}}\right)^{2}+39.45 \cdot x^{\mathrm{sl}}+3.36\right] \cdot c } \\
& +\left[6.84 \cdot\left(x^{\mathrm{sl}}\right)^{2}-6.40 \cdot x^{\mathrm{sl}}+3.64\right]
\end{aligned}
$$

and will be used for comparison purposes together with the $C_{b}^{\text {total }}$ values and the experimental values (Freundlich isotherm parameters in Table 6) at two different free chloride concentrations. Here, the concentration of $0.5 \mathrm{M}$ was chosen as significant, being the usual chloride concentration of sea water [1]. The second chosen concentration is $1.8 \mathrm{M}$, as used in the Rapid Chloride Migration test [4]. Fig. 9 shows the experimental isotherms, the $\mathrm{C}_{\mathrm{b}}^{\text {total }}$ and $\mathrm{C}_{\mathrm{b}}^{\text {Dhir }}$ at

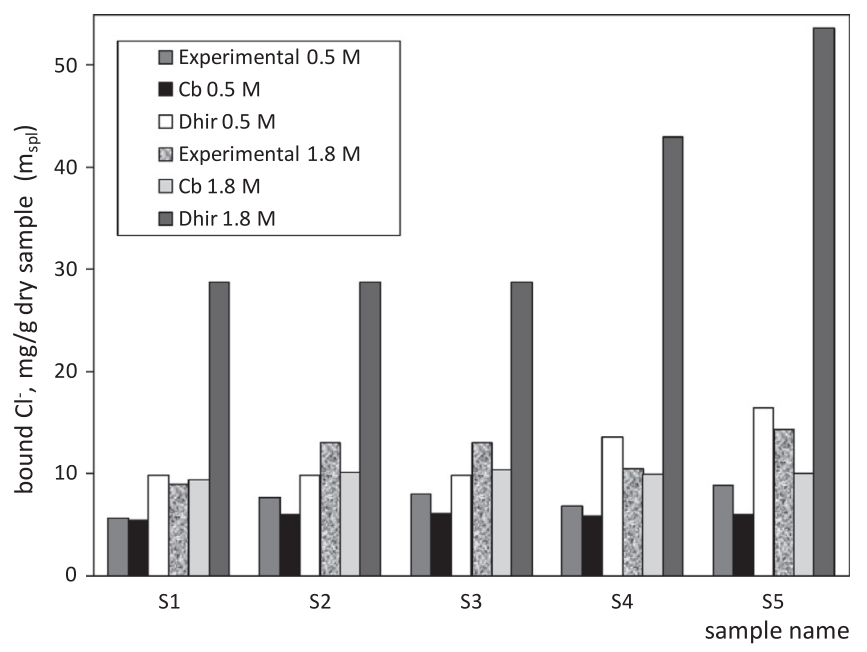

Fig. 9. Chloride binding capacity of each hydrated paste (see Table 6) with experimental values at free chloride concentrations of $0.5 \mathrm{M}$ and $1.8 \mathrm{M}$ (see Section 6). 
these two free chlorides concentrations. The results show that the proposed model estimates the binding chloride ability of slagblended pastes with enough accuracy, the relative errors to experimental values being between $3.5 \%$ and $29 \%$, with an average of $\sim 17 \%$ over the whole interval of free chloride concentrations. These errors can have a number of possible sources, including the errors of the initial OPC chloride binding model of $\sim 8 \%$ [1], the scatter of the experimental data used, the estimation of hydration degree based on age of the sample and its composition and the role of slag-generated alumina during the hydration process. The latter parameter was observed to have the highest impact on the estimation of chloride binding ability. The results presented in this study are based on the hydration of a slag with a low A/S ratio (as categorized by $[15,19,20], A / S=0.16$ in the slag). For slags with a higher initial $\mathrm{A} / \mathrm{S}$ ratio, the incorporation of $\mathrm{A}$ in the $\mathrm{C}-\mathrm{S}-\mathrm{A}-\mathrm{H}$ structure will also be increased. Moreover, if the alumina is sufficient, HO-AFm could be formed after the complete reaction of the sulphates, and also contribute to the chloride binding. As explained in [1], the high chloride binding ability of HO-AFm will have a significant influence on the total bound chlorides, even if this hydration product is formed only in small quantities. However, the complex relationship between the AFm phases in the hydrated cement matrix (as detailed in [1]) can mostly account for the underestimation of the chloride binding capacity.

Also from Fig. 9 it can be seen that the model proposed by Dhir et al. [7] overestimates the chloride binding capacity of the slag-blended cement pastes, with relative errors between 40 and $100 \%$ for a free chloride concentration of $0.5 \mathrm{M}$. For larger free chloride concentrations, however, the model predicts 3-3.5 times more bound chlorides than what is measured experimentally.

\section{Summary and conclusions}

Two hydration models [10-14] were combined in this study in order to describe the phase assemblage of a hydrated slag-blended cement paste. New insights into the hydration products of slagblended cements [15-20,27] were employed to explain the interaction between the two components of the binder: the OPC and the slag, respectively. Separate hydration degrees were estimated for the two components [26] and the mass of each sample at $11 \%$ r.h. was computed accordingly. The considered phases able to bind chlorides are the AFm phases and the $\mathrm{C}-\mathrm{S}-\mathrm{A}-\mathrm{H}$ phase. The latter one is considered to be able to incorporate alumina in its structure [13-15,19,20], and its C/S and A/S ratios are taken into account when estimating its chloride binding capacity [32].

The chloride binding capacity of slag-blended cement pastes is considered to be due to three processes: the hydration of the OPC component, the one of the slag component, which both generate chloride-binding hydrated phases, and the interaction of the two, which modifies the final phase assemblage. This third component can, in its turn, be attributed to a number of factors: the decrease of the $\mathrm{C} / \mathrm{S}$ ratio of the $\mathrm{C}-\mathrm{S}-\mathrm{A}-\mathrm{H}$ phase, the incorporation of alumina in the $\mathrm{C}-\mathrm{S}-\mathrm{A}-\mathrm{H}$ structure, the transformation of $\mathrm{HO}-\mathrm{AFm}$ into $\mathrm{SO}_{4}-\mathrm{AFm}$ in the presence of sulphates and the decreasing amount of ettringite formed with the increase of the slag content of the blend. All these factors are quantified in the present model, in order to ensure the accuracy of the chloride binding estimation. The importance of quantifying separately the chemically and physically bound chlorides in order to evaluate the influence of the slag composition is also underlined in [33]. The reduction of the $\mathrm{C} / \mathrm{S}$ ratio of the $\mathrm{C}-\mathrm{S}-\mathrm{A}-\mathrm{H}$ phase as well as the influence of the alumina content of the slag are also concluded in [34,35].

When taking into consideration the breakdown of the bound chlorides by hydrated phase, it is observed that the $\mathrm{C}-\mathrm{S}-\mathrm{A}-\mathrm{H}$ phase is roughly responsible for two thirds of the bound chlorides, the rest being attributed to the AFm phases. These percentages vary slightly, the contribution of $\mathrm{C}-\mathrm{S}-\mathrm{A}-\mathrm{H}$ decreasing by $\sim 10 \%$ with the increase of the free chlorides concentration between 0.5 and $1.8 \mathrm{M}$, while the contribution of $\mathrm{SO}_{4}-\mathrm{AFm}$ increases by $\sim 20 \%$. The contribution of the AFm phases could be much higher, if the considered slag had a higher initial A/S ratio. According to [25], the slag considered in this study has an intermediate A/S ratio. Its increase would determine multiple changes on the microstructure of the hydrated paste, the $\mathrm{A} / \mathrm{S}$ ratio of $\mathrm{C}-\mathrm{S}-\mathrm{A}-\mathrm{H}$ and the amount of AFm phase being the most important.

Besides the A content, the $\mathrm{C}$ content of the slag is also important for the final $\mathrm{C} / \mathrm{S}$ ratio of the $\mathrm{C}-\mathrm{S}-\mathrm{A}-\mathrm{H}$ phase, while its amount is influenced by the $S$ content of the slag. Perhaps the most influential factor (together with the A content) on the chloride binding ability of the past is the $\bar{S}$ content of the slag. The sulphate content will determine the amount of HO-AFm formed, which is the hydration product with the highest chloride binding capacity from all hydration products studied in this paper and in [1]. Therefore, just like in the case of the OPC composition, but perhaps even more important, the composition of the slag is crucial to the maximum chloride binding capacity of the hydrated paste.

The presented model takes into account all these factors, together with the $w_{0} / b_{0}$ ratio and age of sample, through the two degrees of hydration estimated. By taking into consideration these compositional and curing factors, the accuracy of the model is highly improved from a previous model from literature, which only takes into account the slag content of the mix. This holds true for all free chloride concentrations considered, but the difference becomes more important at higher free chloride concentrations.

The importance of the content of both aluminate phases and sulphates in the initial binder composition is highlighted by the findings of this study.

\section{Acknowledgements}

The authors would like to express their gratitude towards the Cement-Concrete-Immobilisates sponsor group at TU Eindhoven: Graniet-Import Benelux, Kijlstra Betonmortel, Struyk Verwo, Attero, Enci, Provincie Overijssel, Rijkswaterstaat Zee en Delta - District Noord, Van Gansewinkel Minerals, BTE, V.d. Bosch Beton, Selor, Twee "R" Recycling, GMB, Schenk Concrete Consultancy, Geochem Research, Icopal, BN International, Eltomation, Knauf Gips, Hess ACC Systems, Kronos, Joma, CRH Europe Sustainable Concrete Centre, Cement\&BetonCentrum and Heros (in chronological order of joining) for making this research possible, and to Dr. P. Spiesz and Dr. D. Florea for their help and advice on this manuscript.

\section{References}

[1] Florea MVA, Brouwers HJH. Chloride binding related to hydration products, Cem Concr Res 2012;42:282-90.

[2] Yuan Q, Shi C, De Schutter G, Audenaert K, Deng D. Chloride binding of cementbased materials subjected to external chloride environment - a review. Constr Build Mater 2009;23:1-13.

[3] Justnes H. A review of chloride binding in cementitious systems. Cem Concr Nordic Concr Res 1996;21:1-6.

[4] Spiesz P, Brouwers HJH. Influence of the applied voltage on the Rapid Chloride Migration RCM test. Cem Concr Res 2012;42:1072-82.

[5] Arya C, Xu Y. Effect of cement type on chloride binding and corrosion of steel in concrete. Cem Concr Res 1995;25:893-902.

[6] Zibara H. Binding of external chloride by cement pastes. PhD thesis; 2001.

[7] Dhir RK, El-Mohr MAK, Dyer TD. Chloride binding in GGBS concrete. Cem Concr Res 1996;26:1767-73.

[8] Luo R, Cai Y, Wang C, Huang X. Study of chloride binding and diffusion in GGBS concrete. Cem Concr Res 2003:33:1-7.

[9] Xu Y. The influence of sulphates on chloride binding and pore solution chemistry. Cem Concr Res 1997;27:1841-50.

[10] Brouwers HJH. The work of Powers and Brownyard revisited: Part 1. Cem Concr Res 2004;34:1697-716.

[11] Brouwers HJH. The work of Powers and Brownyard revisited: Part 2. Cem Concr Res 2005;35:1922-36. 
[12] Brouwers $\mathrm{HJH}$. A hydration model of Portland cement using the works of Powers and Brownyard, Eindhoven University of Technology, Portland Cement Association; 2011. ISBN: 978-90-6814-184-9.

[13] Chen W, Brouwers HJH. The hydration of slag, Part 1: reaction models for alkali-activated slag. J Mater Sci 2006;42:428-43.

[14] Chen W, Brouwers HJH. The hydration of slag, Part 2: reaction models for blended cement. J Mater Sci 2006;42:444-64.

[15] Taylor R, Richardson IG, Brydson RMD. Composition and microstructure of 20 year-old ordinary Portland cement-ground granulated blast-furnace slag blends containing 0 to 100\% slag. Cem Concr Res 2010;40:971-83.

[16] Escalante JI, Gomez LY, Johal KK, Mendoza G, Mancha H, Mancha J. Reactivity of blast-furnace slag in Portland cement blends hydrated under different conditions. Cem Concr Res 2001;31:1403-9.

[17] Hill J, Sharp J. The mineralogy and microstructure of three composite cements with high replacement levels. Cem Concr Compos 2002;24:191-9.

[18] Lothenbach B, Scrivener K, Hooton RD. Supplementary cementitious materials. Cem Concr Res 2011;41:1244-56.

[19] Richardson IG, Cabrera JG. The nature of C-S-H in model slag-cements. Cem Concr Compos 2000;22:259-66.

[20] Richardson IG, Brough AR, Groves GW, Dobson CM. The characterization of hardened alkali-activated blast-furnace slag pastes and the nature of the calcium silicate hydrate C-S-H phase. Cem Concr Res 1994;24:813-29.

[21] Taylor HWF. Cement Chemistry. London: Academic Press Ltd.; 1992.

[22] Adolfsson D, Robinson R, Engström F, Björkman B. Influence of mineralogy on the hydraulic properties of ladle slag. Cem Concr Res 2011;41:865-71.

[23] Puertas F, Varela MTB, Domínguez R. Hydration of $4 \mathrm{CaO} \mathrm{Al}_{2} \mathrm{O}_{3} \cdot \mathrm{Mn}_{2} \mathrm{O}_{3}$ in the absence and the presence of gypsum. A comparative study with the hydration of $4 \mathrm{CaO} \cdot \mathrm{Al}_{2} \mathrm{O}_{3} \cdot \mathrm{Fe}_{2} \mathrm{O}_{3}$. Cem Concr Res 1993;23:20-32.

[24] Stöber S, Redhammer G, Schorr S, Prokhnenko O, Pöllmann H. Structure refinements of members in the brownmillerite solid solution series
$\mathrm{Ca}_{2} \mathrm{Al} x\left(\mathrm{Fe}_{0.5} \mathrm{Mn}_{0.5}\right)_{2}-\chi \mathrm{O}_{5+\delta}$ with $1 / 2 \leqslant x \leqslant 4 / 3$. J Solid State Chem 2013:197:420-8.

[25] Richardson IG. The nature of $\mathrm{C}-\mathrm{S}-\mathrm{H}$ in hardened cements. Cem Concr Res 1999;29:1131-47.

[26] Lumley JS, Gollop RS, Moir GK, Taylor HFW. Degrees of reaction of the slag in some blends with Portland cements. Cem Concr Res 1996;26:139-51.

[27] Matschei T, Lothenbach B, Glasser FP. The AFm phase in Portland cement. Cem Concr Res 2007;37:118-30.

[28] Kayali O, Khan MSH, Ahmed MS. The role of hydrotalcite in chloride binding and corrosion protection in concretes with ground granulated blast furnace slag. Cem Concr Compos 2012;34:936-45.

[29] Ben Haha M, Lothenbach B, Le Saout G, Winnefeld F. Influence of slag chemistry on the hydration of alkali-activated blast-furnace slag-Part I: effect of MgO. Cem Concr Res 2011;41:955-63.

[30] Hirao H, Yamada K, Takahashi H, Zibara H. Chloride binding of cement estimated by binding isotherms of hydrates. J Adv Concr Technol 2005;3:77-84.

[31] Birnin-Yauri UA, Glasser FP. Friedel's salt, $\mathrm{Ca}_{2} \mathrm{Al}(\mathrm{OH})_{6}(\mathrm{Cl}, \mathrm{OH}) \cdot 2 \mathrm{H}_{2} \mathrm{O}$ : its solid solutions and their role in chloride binding. Cem Concr Res 1998;28:1713-23.

[32] Viallis-Terrisse $H$. Interaction des Silicates de Calcium Hydratés, principaux constituants du ciment, avec les chlorures d'alcalins. Analogie avec les argiles. PhD thesis; 2006.

33] Baroghel-Bouny V, Wang X, Thiery M, Saillio M, Barberon F. Prediction of chloride binding isotherms of cementitious materials by analytical model or numerical inverse analysis. Cem Concr Res 2012;42:1207-24.

[34] Thomas MDA, Hooton RD, Scott A, Zibara H. The effect of supplementary cementitious materials on chloride binding in hardened cement paste. Cem Concr Res 2012;42:1-7.

[35] Loser R, Lothenbach B, Leemann A, Tuchschmid M. Chloride resistance of concrete and its binding capacity - comparison between experimental results and thermodynamic modelling. Cem Concr Compos 2010;32:34-42. 